\title{
MATERNAL FACTORS OF PRE-ECLAMPSIA DEVELOPMENT
}

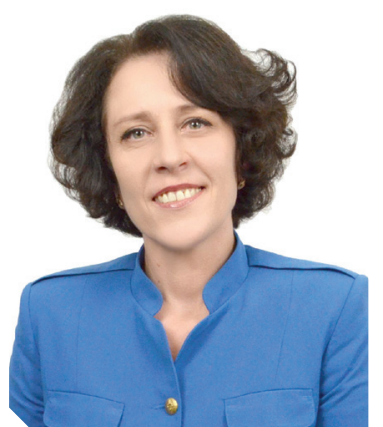

L.I. BERLINSKA

assistant, Department of Obstetrics and Gynecology, Odesa National

Medical University, Odesa ORCID: 0000-0002-7571-1400

V.G. MARICHEREDA

MD, professor, Department of Obstetrics and Gynecology, Odesa National Medical University, Odesa ORCID: 0000-0002-1611-3654

\section{M.Y. HOLUBENKO}

MD, professor, Department of Obstetrics and Gynecology, Odesa National Medical University, chief physician of the Maternity Hospital No. 2, Odesa

ORCID: 0000-0001-9862-1208

\section{O.M. PAVLOVSKA}

PhD, associate professor, Department of Obstetrics and Gynecology, Odesa National Medical University, Odesa ORCID: 0000-0001-95499032

\section{Contacts:}

Liudmyla I. Berlinska Odesa National Medical University, Department of Obstetrics and Gynecology Valikhovskiy Lane, 2 65082, Odesa, Ukraine email: ludaberlinskaja@gmail.com Tel.: + 38 (093) 3045707

\section{INTRODUCTION}

Preeclampsia (PE) is one of the main causes of complications during pregnancy, leading to maternal and perinatal morbidity and mortality, especially at early stages. The prevalence of PE varies from $2 \%$ to $5 \%$ among pregnant women and depends on the level of development in various countries worldwide [1]. There is evidence that women who had PE at older have an increased risk of death associated with cardiovascular disease, hypertension, stroke, renal failure, metabolic syndrome, and diabetes $[2,3]$. Female's life expectancy is reduced by 10 years in average. Despite the number of potential factors studies, the etiology of $\mathrm{PE}$ is not reduced to a single mechanism that leads to a cascade of successive events resulting in multiple organ failure. The priority of the international professional community is to improve the identification of women at high risk for PE in order to initiate the necessary preventive measures targeting reduction of morbidity and improvement of placentation. It is recommended to conduct a universal comprehensive screening at early gestation period by the end of the first trimester for all pregnant women, which includes the identification of risk factors and biomarkers. According to the recommendations of the Federation International of Gynecologists and Obstetricians (FIGO), high (PE in previous births, chronic hypertension, type 1 or 2 diabetes, kidney disease, autoimmune diseases, multiple pregnancy) and moderate (no birth history, obesity, family history of $\mathrm{PE}$, family history of $\mathrm{PE}$, age over 35 years, interval between pregnancies over 10 years and more, in vitro fertilization (IVF)) risk factors for PE [1]. At present, in order to improve the prediction of $\mathrm{PE}$ at the initial stage of treatment, the urgent problem is to determine the most important maternal factors. This can help reduce the development and reduce the incidence of PE complications through timely prevention and treatment.

Study objective: to determine the most important maternal factors for PE predicting, which are used in screening of women when registered for pregnancy.

\section{MATERIALS AND METHODS}

In 2018-2020 a prospective cohort study of 91 pregnant women in the first trimester of gestation was conducted on the basis of the Women's Clinic and Obstetric Hospital of KU Maternity Hospital №2 (Odesa), as well as at the medical commercial laboratory. Study group included 56 (61.54\%) women in the main group who according to the FIGO recommendations (2019) had a number of maternal factors associated with PE development, and 35
(38.46\%) women in control group were healthy. Study group included pregnant women with the following factors: history of kidney disease - 21 patients (23.08\%), PE during previous pregnancies -5 patients $(9.09 \%)$, multiple pregnancies -2 patients $(2.2 \%)$, chronic hypertension -3 patients (33\%); antiphospholipid syndrome (APS) - 2 patients $(2.2 \%)$; IVF - 5 patients (5.49\%); first pregnancy 23 (25.27\%), body mass index $(\mathrm{BMI})>30 \mathrm{~kg} / \mathrm{m}^{2}$ before pregnancy $15(16.48 \%),>35$ years aged women - 22 patients $(24.18 \%), \mathrm{PE}$ in mother -8 patients $(8,79 \%)$, the interval of previous pregnancy $>10$ years 9 patients (8.19\%) (Table).

The general exclusion criteria were cancer, tuberculosis, severe somatic pathology at the stage of decompensation, mental disease, chronic alcoholism, drug addiction and trauma during pregnancy, which led to obstetric complications.

Further division into subgroups was based on the International Society for the Study of Hypertension in Pregnancy recommendations (ISSHP) and approved by the FIGO for PE detection [1, 4]. PE was determined by systolic blood pressure $\geq 140 \mathrm{~mm} \mathrm{Hg}$ or diastolic pressure $\geq 90 \mathrm{~mm} \mathrm{Hg}$ when measured at least 2 times every 4 hours in women who had normal blood pressure prior to pregnancy, or with the following conditions detected at 20th gestation week or later: proteinuria ( $\geq 30 \mathrm{mg} / \mathrm{mol}$ ) or other pathological conditions, including acute renal failure (creatinine level $\geq 90$ $\mu \mathrm{mol} / \mathrm{l})$, liver disease with or without pain in the right upper quadrant of the abdomen or epigastric pain, neurological or hematological complications, utero-placental dysfunction. Thus $28.57 \%$ of pregnant women were included into PE subgroup, and $71.43 \%$ were women who had no PE.

\section{Statistical analysis}

The data obtained in the study were entered into the MS-Excel database and analyzed using the statistical program MedCalc for PC, version 12.7.0 (MedCalc Software, Belgium). Descriptive analysis was used for intergroup comparison to determine the most important factors in the development of $\mathrm{PE}$. Receiver operating characteristic (ROC) with area under the curve (AUC) were used. Group comparisons were performed using one of the ANOVA methods. A value of $p<0.05$ was considered statistically significant.

\section{RESULTS AND DISCUSSION}

As for the $100 \%$ of study group, PE has been found in $26(28.57 \%)$ of pregnant women: 21 $(23.08 \%)$ in the main group and $5(5.49 \%)$ in the control group. The average age of pregnant wom- 


\begin{tabular}{|c|c|c|c|c|c|c|c|c|c|c|c|}
\hline \multicolumn{12}{|c|}{ Table. Distribution of maternal factors in PE screening } \\
\hline $\begin{array}{l}\text { Groups and } \\
\text { subgroups }\end{array}$ & $\begin{array}{l}\text { Obesity, } \\
\%\end{array}$ & $\begin{array}{l}\text { First pregnancy, } \\
\%\end{array}$ & $\begin{array}{l}\text { APS, } \\
\%\end{array}$ & $\begin{array}{l}\text { IVF, } \\
\%\end{array}$ & $\begin{array}{l}\text { Maternal age } \\
>35 \text { years, } \%\end{array}$ & $\begin{array}{c}\text { Family history } \\
\text { of PE, } \%\end{array}$ & $\begin{array}{l}\text { Previous history } \\
\text { of PE, } \%\end{array}$ & $\begin{array}{l}\text { Kidney } \\
\text { disease, \% }\end{array}$ & $\begin{array}{c}\text { Multiple } \\
\text { pregnancy, \% }\end{array}$ & $\begin{array}{c}\text { Pregnancy interval } \\
>10 \text { years, } \%\end{array}$ & $\begin{array}{c}\text { Chronic } \\
\text { hypertension, \% }\end{array}$ \\
\hline $\begin{array}{l}\text { Main group } \\
(61.54 \%)\end{array}$ & 16.48 & 25.27 & 2.2 & 5.49 & 24.18 & 8.79 & 9.09 & 23.08 & 2.2 & 8.19 & 3.33 \\
\hline $\begin{array}{c}\text { Control group } \\
(38.46 \%)\end{array}$ & 1.1 & 14.29 & - & - & 5.49 & - & - & - & - & 0.91 & - \\
\hline $\begin{array}{l}\text { A subgroup } \\
\text { of pregnant } \\
\text { women with } \\
\text { PE (28.57\%) }\end{array}$ & 6.59 & 14.29 & 1.1 & 2.2 & 8.79 & 3.3 & 5.45 & 6.59 & 1.1 & 1.82 & 2.22 \\
\hline $\begin{array}{l}\text { Subgroup } \\
\text { of pregnant } \\
\text { women } \\
\text { without PE } \\
(71.43 \%)\end{array}$ & 10.99 & 25.27 & 1.1 & 3.3 & 20.88 & 5.49 & 3.64 & 16.48 & 1.1 & 7.28 & 1.11 \\
\hline
\end{tabular}

en of 30 years is steadily increasing. Women over the age of 35 had an increased risk of maternal and perinatal complications; the most dangerous was PE [5]. The age distribution of women in the study group was $15-42$ years, the average age was 30.53 \pm 0.62 (95\% confidence interval $(\mathrm{Cl}): 29.3-31.75, \mathrm{p}=0.006)$; the age distribution in the main group was $31.88 \pm 0.86(95 \% \mathrm{Cl}$ : 30.19-33.56) and was higher compared to control group 28.37 \pm 0.74 (95\% Cl: 26.92-29.82). The following statistical difference was found between subgroups of women who developed PE (30.65 $\pm 1.25,95 \% \mathrm{Cl}: 28.21-33.1)$ and without PE $(31.83 \pm 1.12$, $95 \% \mathrm{Cl}: 29.63-34.03)$ and in the control group $(28.9 \pm 0.78,95 \%$ $\mathrm{Cl}: 27.36-30.44), \mathrm{F}=2,009, \eta^{2}=0.044, p=0.14$. The average age of women in the subgroups did not differ $(p>0.05)$ (Fig. 1).

ROC did not show a significant difference in AUC when analyzing the age of pregnant women in relation to $\mathrm{PE}$ : in women with PE AUC was 0.54 , in women without PE it was 0.46 ; therefore the quality of model is not satisfactory. Thus, the direct association between PE and age increase in our study has not been confirmed.

Number of women over 35 years in the main group was 27 (29.67\%), with 8 (8.79\%) developing PE (Fig. 2). There is no statistical significance between women older than 35 years and older women in the PE risk ( $p>0.05)$. Thus, the analysis of study data did not confirm an association of age 35-42 years with PE development. Our results are consistent with studies by M. Ndiaye et al.: they reported that the age $>35$ is associated with 1.6 fold increase of high blood pressure compared with women from 19-34 years aged group before and after adjustment for parity, multiple pregnancy and diabetes. However, the eclampsia risk is 4 times higher in women under 35 , especially in adolescents who do not have additional risks of high blood pressure [6].

The growing trend for obesity worldwide in terms of prevalence among pregnant women is $15-38 \%$. The exact mechanisms of obesity and PE association are not clear yet. Hyperinsulinemia plays an important role in the pathogenesis of PE in overweight patients. The central nervous system and kidneys remain sensitive to insulin, while hyperinsulinemia is a factor that activates the sympathetic division of the autonomic nervous system and increased vascular tones. Under conditions of sympathicotonia, the filtration of glucose by glomeruli increases, which leads to increased reabsorption of sodium in the proximal tubules of the nephron. It results in fluid and electrolytes retention. The direct action of insulin under the conditions of hyperinsulinemia also helps to reduce the level of intracellular potassium and to increase the level of calcium and sodium. The
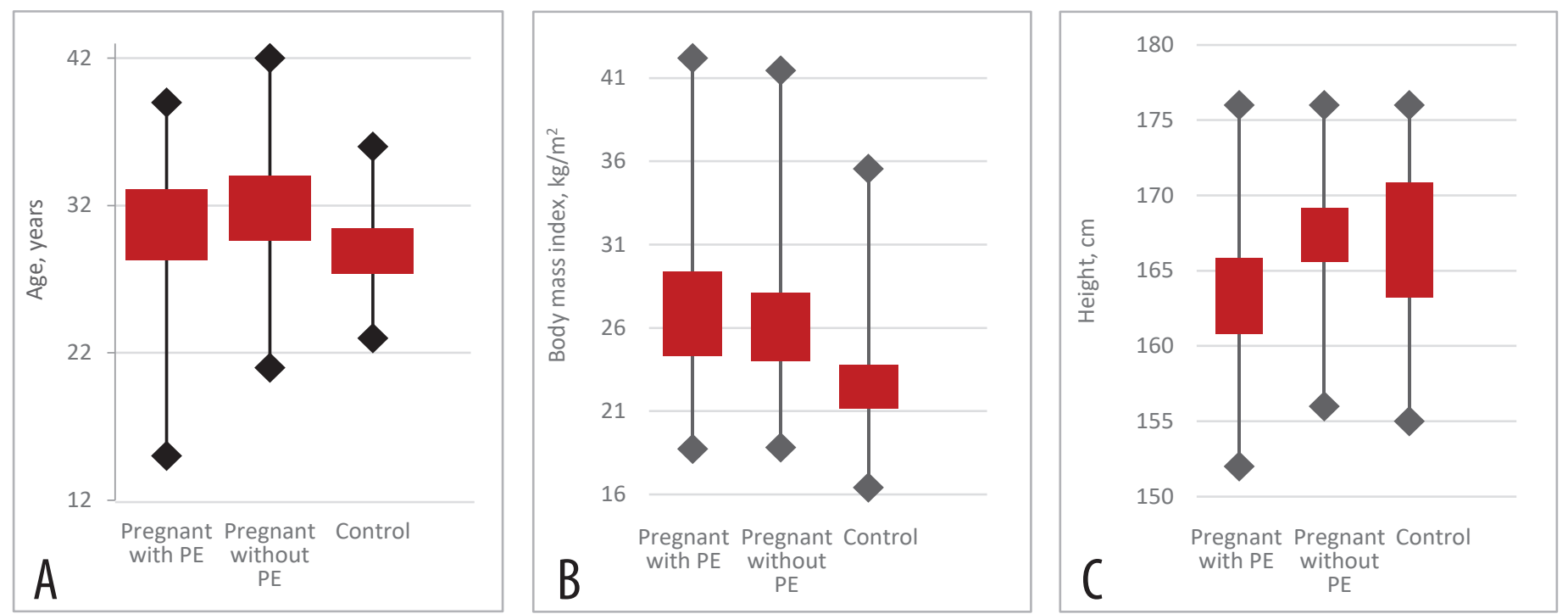

Figure 1. Comparison of age (a), BMI (b) and height (c) among the examined pregnant women with and without PE and in the control group 


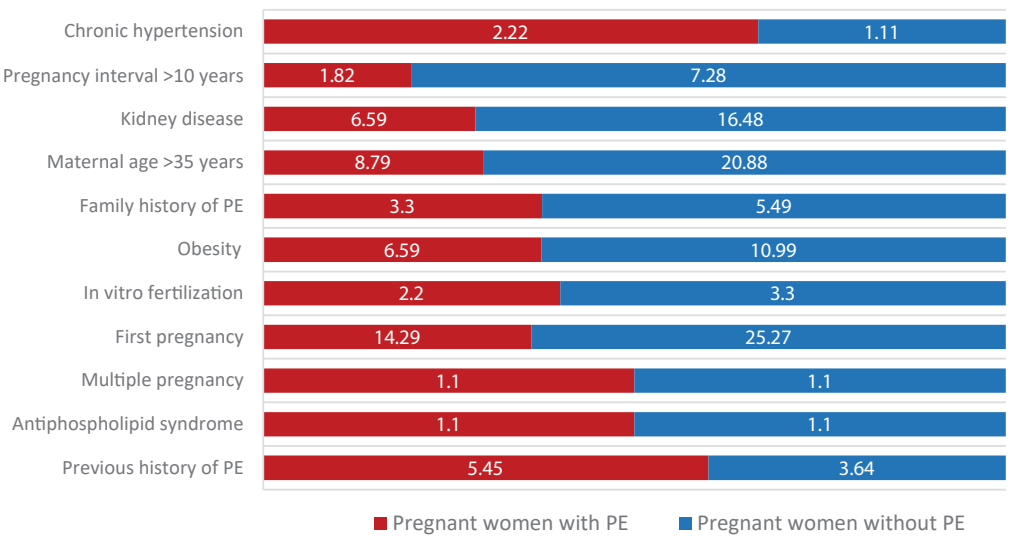

Figure 2. Comparison of age (a), BMI (b) and height (c) among the examined pregnant women depending on the PE presence and in the control group

effect of catecholamines is significantly increased. It is believed that endothelial dysfunction, microthrombosis and hyperinsulinemia in obese women lead to impaired implantation, trophoblast invasion and placentation, which can further lead to the development and severe course of PE. J. Čerkez Habek et al. demonstrated statistically significant differences in BMI between groups of females with PE and control groups at the middle gestation age, as well as in the average pre-gestation values of $B M I$. The authors suggest that increased pre-gestation BMI is a risk of PE during pregnancy [7]. In order to assess the association between overweight or obesity and $\mathrm{PE}, \mathrm{J}$. Poorolajal and $\mathrm{E}$. Jenabi conducted a meta-analysis that included 23 studies with 1,387,599 participants. PE was associated with overweight (OR (odds ratio) $=1.73 ; 95 \% \mathrm{Cl}: 1.59-1.87$; 21 studies) and obesity (OR $=3.15 ; 95 \% \mathrm{Cl}$ : $2.96-3.35 ; 22$ studies). The authors report that the index of excess body weight is significantly associated with an increased PE risk. Therefore, overweight and obesity can be considered as a PE predictor [8].

The average weight of women before pregnancy in the main group in our study was $73.69 \pm 2.48 \mathrm{~kg}(95 \% \mathrm{Cl}: 68.83-78.54)$ with a BMI of $26.7 \pm 0.86$ (95\% Cl: $25-28.39)$, while in the control group body weight was $61.85 \pm 1.48 \mathrm{~kg}$ (95\% Cl: 58.96-64.75) and BMI was $22.5 \pm 0.59$ (95\% Cl: 21.35-23.65); thus in women with PE risk there was a statistically significant increased weight and $\mathrm{BMI}$ compared to healthy pregnant women $(p<0.001)$. Women who subsequently developed PE had body weight $71.8 \pm 3.66$ $\mathrm{kg}(95 \% \mathrm{Cl}: 64.63-78.98)$ with a BMI 26.83 \pm 1.29 (95\% Cl: 24.31-29.36), the average weight of pregnant women without $\mathrm{PE}$ was $73 \pm 3.08$ kg (95\% Cl: 65.37-87.63) with a BMI $26.03 \pm 1.05$ (95\% Cl: 23.98-28); in the control group the respective values were $62.32 \pm 1.67 \mathrm{~kg}(95 \% \mathrm{Cl}: 59.05-65.58)$ with a BMI $22.46 \pm 0.67$ (95\% Cl: 21.16-23.77) with a statistical significant difference of $p$-values for weight $(p<0.05)$ and BMI $(p<0.05$, $\left.F=5.028, \eta^{2}=0.0103\right)$. The ROC analysis of AUC of BMI for PE in pregnant women showed an average quality (0.62) in women with $P E$, and has been unsatisfactory in pregnant women without PE (0.57) and in the control group (0.32), which proves BMI association with the PE development.

The frequency of obesity among pregnant women was $16(17.58 \%)$, PE has been developed in 6 (6.59\%) women, of whom the first degree of obesity was reported in 3 females (3.3\%), the second degree has been reported in 1 female $(1.1 \%)$ and the third degree has been reported in $2 \mathrm{fe}-$ males (2.2\%) (Fig. 2). There was no statistical significance for PE development associated with the obesity degree (Pearson's agreement criterion 1.37, $p<0.05$ ). Thus, in our study we found a direct proportional association between the PE development and an increased BMI before pregnancy, even in overweight; however, the association with the obesity degree has not been demonstrated. This is consistent with the conclusions of other authors [7-10].

Height comparison between women from the main group $(166.05 \pm 0.81 \mathrm{~cm}$, 95\% Cl: 164.46-167.65) and the control group $(166.23 \pm 1.74 \mathrm{~cm}, 95 \% \mathrm{Cl}: 162.82-$ 169.64) demonstrated no statistical difference $(p>0.05)$. Statistically significant results were observed between women who developed PE $(163.35 \pm 1.26 \mathrm{~cm}, 95 \%$
Cl: 160.87-165.82) compared to women who did not develop PE $(167.23 \pm 1.02 \mathrm{~cm}$, $95 \%$ Cl: 165.23-169.2), $p<0.05$, Cohen's index 0.5 (95\% Cl: 0.38-0.62). ROC showed a significant difference in AUC in pregnant women with PE - 0.28 and without PE 0.72 . It can be assumed that women with lower height have an increased PE risk (Fig. 1). The association between maternal lower height and PE has also been confirmed in previous studies [11, 12].

The first pregnancy is one of the leading factors in the PE development, which accounts for $4.1 \%$; it is believed that the influence of the new antigen is involved in the pathogenesis. Our study included 36 (39.56\%) women with first pregnancy, 23 (25.27\%) of which in the main group and 13 (14.29\%) in the control group; PE has been developed in 13 (14.29\%) pregnant women, but no statistical significance has been reported ( $p>0.05$ ) (Fig. 2). Among the risk factors that led to $P E$, statistically significant results were observed when combining the first pregnancy with a history of kidney disease $(p<0.05)$ and reached $13(14.29 \%)$. Risk factors such as age $>35$ years were reported in 6 females (6.59\%), obesity in 5 females (5.49\%), PE in the mother has been reported in 5 females $(5.49 \%)$, multiple pregnancy - in 1 female (1.1\%), IVF - in 1 female $(1.1 \%)$ and antiphospholipid syndrome - in 1 female (1.1\%) were statistically insignificant. Thus, the most significant influence on the development of PE in first time pregnant women is a history of chronic kidney disease.

$P E$ prevalence of in subsequent pregnancies was also reported in 13 females (14.29\%). Thus, PE is influenced not only by the new antigen, but also by other factors influencing the development of endotheliosis. The increased risk of PE recurrence in subsequent pregnancies is associated with diastolic blood pressure levels and early onset in the first pregnancy, namely the risk increases proportionally $[13,14]$. In our study, recurrent PE was reported in 3 females (5.45\%), statistically significant results were observed when combined with PE in mother, $p=$ 0.011 (Fig. 2). PE risk is considered lower during the second pregnancy if the fetus is conceived with the same partner, but the chances of $P E$ is increased along with the interval between labors. Women with intervals between pregnancies over 6 years have a higher risk of developing PE 
compared to those with intervals between pregnancies ranging from one to two years $[15,16]$. Women in the main group who gave birth for the second time and more (55 (60.44\%) included $10(18.18 \%)$ pregnant women with intervals between pregnancies of 10 years and more), of which PE has been developed in 2 females (3.64\%) (Fig. 2). Only the age of women over 35 years was noted as a statistically significant factor $(p=0.008)$.

$P E$ risk in twin pregnancies is 3-4 fold higher compared to singleton pregnancies, regardless of maternal age, parity, level of education, smoking, concomitant maternal pathology or IVF-status [17]. The group with PE included $1.1 \%$ females with twins, while the level in study group was $2.2 \%$ (Fig. 2). Statistically significant factors in combination with multiple pregnancies were not observed.

Renal dysfunction is an essential component in the pathogenesis of PE and is considered one of the leading factors among extragenital diseases. Diagnosing PE in pregnant women with chronic renal failure is very difficult due to preexisting proteinuria. PE risk ranges from $5.3 \%$ to $8 \%$ [18]. Changes occur in a woman's body during physiological pregnancy resulted in adaptation disorders and may lead to the renal failure development or exacerbate the course of pre-existing kidney disease, which in turn can lead to PE [19, 20]. Our study included 21 (23.08\%) women with a history of kidney disease; PE has been developed in $6(6.59 \%)$ cases in combination with factors such as first pregnancy, chronic hypertension and APS (Fig. 2).

Chronic hypertension increases the PE development by 3-5 times, especially when the hypertension duration is over 5 years and in combination with some factor such as previous PE [21]. Chronic hypertension was reported in 3 (3.33\%) pregnant women in the main group, PE was developed in 2 females $(2.22 \%)$ with a duration of hypertension of $>5$ years $(1.1 \%)$ and in combination with chronic kidney disease (1.1\%) (Fig. 2).

PE development is from $13 \%$ to $36 \%$ depending on the markers of autoimmune diseases [22]. One of the most important factors in the PE development is APS. 1,000 women with a positive APS score were included in the prospective and retrospective analysis at least twice according to European Registry for Obstetric APS. Miscarriages were the most common clinical manifestation in 386 cases (38.6\%). Moreover, the presence of early PE and early fetal development delay were found in 181 (18.1\%) and 161 (16.1\%) patients, respectively [23]. The main group in our study included 2 females (2.2\%) with APS, PE was developed in 1 patient $(1.1 \%)$, and was associated with age $>35$ years and a history of kidney disease (Fig. 2).

IVF is a successful treatment for infertility, which is reported to be associated with an increased risk of adverse obstetric and perinatal complications, including PE due to placental abruption. However, the history of pregnant women with IVF includes factors that affect the PE development [24]. It is assumed that IVF is accompanied not only by an increased PE risk but also is associated with the PE progression, including exacerbation of diseases and comorbidities [25]. Our study included 5 (5.49\%) pregnant women with a history of IVF with a statistically significant indicator - age over 35 years $(p<0.05)$. PE has been developed in 2 females $(2.2 \%)$, of which $1.1 \%$ of pregnant women developed PE in combination with such factors as BMI $>30 \mathrm{~kg} / \mathrm{m}^{2}$ and the interval between pregnancies over 10 years, and $1.1 \%$ of patients had no factors of PE (Fig. 2).
The analysis identified risk factors for PE development (risk decrease sequence):

1. $P E$ during a previous pregnancy: $\mathrm{OR}=6(95 \% \mathrm{Cl} 0.88-40.87)$.

2. Multiple pregnancy: $\mathrm{OR}=2,56(95 \% \mathrm{Cl} 0,15-42,53)$ and APS: $\mathrm{OR}=2,56(95 \% \mathrm{Cl} 0,15-42,53)$.

3. The first pregnancy: $\mathrm{OR}=1.83$ (95\% Cl 0.73-4.59).

4. IVF: OR = $1.72(95 \% \mathrm{Cl} 0.27-10.96)$.

5. Obesity (BMI >30 kg/m²): OR = 1.65 (95\% Cl 0.53-5.13).

6. $\mathrm{PE}$ in the mother: $\mathrm{OR}=1.57(95 \% \mathrm{Cl} 0.35-7.08)$.

7. Age $\geq 35$ years: $\mathrm{OR}=1.08(95 \% \mathrm{Cl} 0.4-2.89)$.

8. History of renal disease: $\mathrm{OR}=1$ (95\% Cl 0.34-2.94).

9. Interval between pregnancies $>10$ years: $\mathrm{OR}=0.77(95 \% \mathrm{Cl}$ 0.14-4.2).

10. Chronic hypertension: $\mathrm{OR}=0.18$ (95\% Cl 0.02-2.08).

\section{CONCLUSIONS}

The most important risk factor in our prospective study is $\mathrm{PE}$ during previous pregnancy. The second position is occupied by multiple pregnancy and APS. These factors, according to the FIGO recommendations are classified as high risk factors. The first pregnancy, IVF, pre-gestation obesity, the age of pregnant woman $>35$ years (OR is less than 2 but more than 1 ) are classified as moderate factors and coincide with the factors proposed by the communities.

A history of renal disease and chronic hypertension, which is also a high risk factor, were not significant in our study with OR $<1$. However, when factors are combined, especially with chronic renal disease and/or elevated $\mathrm{BMI}$, the PE risk is increases.

Thus, we have demonstrated that thorough monitoring of maternal risk factors helps to predict the PE development, but for more sensitive and specific detection it is necessary to use complex models based on biochemical and Doppler indicators.

\section{REFERENCES/ЛІTEPATУPA}

Poon, L.C., Shennan, A., Hyett, A.J., et al.

"The International Federation of Gynecology and Obstetrics (FIGO) initiative on pre-eclampsia: A pragmatic guide for first-trimester screening and prevention." Int J Gynecol Obstet 145.1 (2019): 1-33. . Bergen, N.E., Schalekamp-Timmermans, S., Roos-Hesselink, J., et al.

"Hypertensive disorders of pregnancy and subsequent maternal cardiovascular health." European Journal of Epidemiology 33 (2018): 763-71. D01: 10.1007/s10654-018-0400-1

3. Lopes, V.A., Spaan, J.J., Cornelis, T.

"Prevalence of chronic kidney disease after preeclampsia." Journal of Nephrology 30 (2017): 403-9.

4. Brown, M.A., Magee, L.A., Kenny, L.C., et al.

"The hypertensive disorders of pregnancy: ISSHP classification, diagnosis and management

recommendations for international practice." Pregnancy Hypertens 13 (2018): 291-310.

Walker, K.F., Thornton, J.G.

"Advanced Maternal Age." Obstetrics, Gynaecology and Reproductive Medicine 26 (2016): 354-7.

DOl: 10.1016/j.ogrm.2016.09.005

6. Mame Diarra Ndiaye, et al.

"The Impact of Extreme Maternal Ages on Hypertensive Disorders of Pregnancy: A Retrospective Cohort

Study in Dakar, Senegal." Open Journal of Obstetrics and Gynecology 10 (2020): 213-20.

Cerkez Habek, J., et al.

"Pregestational obesity - risk factor for preeclampsia." Med Jad 49.1 (2019): 45-9.

8. Poorolajal, J., Jenabi, E.

"The association between body mass index and preeclampsia: a meta-analysis."The Journal of Maternal-

Fetal \& Neonatal Medicine 29.22 (2016): 3670-6.

9. Wajahat Hussain, Muhammad Arif Khan, Muhammad Imran.

"Obesity: A Risk Factor of preeclampsia." Int J Front Sci 3.2 (2019): 104-7.

10. Motedayen, M., Rafiei, M., Rezaei Tavirani, M., et al.

"The relationship between body mass index and preeclampsia: A systematic review and meta-analysis."

Int J Reprod BioMed 17 (2019): 463-72. D01: 10.18502/ijrm.v17i7.4857

11. Lee, Y., Magnus, P.

"Maternal and Paternal Height and the Risk of preeclampsia." Hypertension 71.4 (2018): 666-70. DOl: 10.1161/HYPERTENSIONAHA.117.10477 


\section{Lao, T.T., Hui, A.S.Y., Sahota, D.S., Leung, T.Y.}

"Maternal height and risk of hypertensive disorders in pregnancy". The Journal of Maternal-Fetal \& Neonatal Medicine 32.9 (2019): 1420-5.

DOl: $10.1080 / 14767058.2017 .1410786$

13. Bernardes, T.P. Mol, B.W. Ravelli, A.C.J., et al.

"Recurrence risk of preeclampsia in a linked population-based cohort: Effects of first pregnancy maximum diastolic blood pressure and gestational age." Pregnancy Hypertension 15.32 (2019): 32-6. 14. Galaviz-Hernandez, C., Sosa-Macias, M., Teran, E., et al.

"Paternal Determinants in preeclampsia." Front. Physiol., 07 January 2019 https://doi.org/10.3389/fphys.2018.01870

15. Mignini, L.E., Carroli, G., Betran, A.P., et al.

"Interpregnancy interval and perinatal outcomes across Latin America from 1990 to 2009: a large multi-country study." BJOG 123 (2016):

730-7.

16. Hanley, E.G., Hutcheon, A.J., Kinniburgh, A.B., Lee, L. "Interpregnancy Interval and Adverse Pregnancy Outcomes." Obstetrics \& Gynecology 129.3 (2017): 408-15. D0I: 10.1097/ AOG.0000000000001891
17. Laine, K., Murzakanova, G., Sole, K.B., et al.

"Prevalence and risk of pre-eclampsia and gestational hypertension in twin pregnancies: a population-based register study." BMJ 9.7 (2019): e029908. DOl: 10.1136/bmjopen-2019-029908

18. Bilano, V.L., Ota, E., Ganchimeg, T., et al.

"Risk Factors of Pre-Eclampsia/Eclampsia and Its Adverse Outcomes in Low- and Middle-Income Countries: A WHO Secondary Analysis." PLOS ONE 9 (2014): e91198.

19. Артьоменко, В.В.

Актуальність використання сучасних ниркових біомаркерів для скринінгу раннього розвитку прееклампсії / В.В. Артьоменко,

Л.І. Берлінська // Почки. - 2018. - № 7(2). - С. 81-86.

Artyomenko, V.V., Berlinska, L.I.

"Relevance of the modern renal biomarkers use for the screening of early development of preeclampsia."Kidneys 7.2 (2018): 81-6.

20. Hladunewich, M.A.

"Chronic Kidney Disease and Pregnancy." Seminars in Nephrology 37.4 (2017): 337-46. D0l: 10.1016/.semnephrol.2017.05.005
21. Brumby, C., Aherne, N., Koh, G., et al.

"Risk factors for superimposed preeclampsia in women with chronic hypertension." Pregnancy Hypertens 13.1 (2018): S119. D01:

10.1016/.jpreghy.2018.08.352

22. Elliott, S.E., et al.

"Characterization of antibody specificities associated with preeclampsia.."Hypertension 63 (2014): 1086-93.

23. Alijotas-Reig, J., Esteve-Valverde, E., Ferrer-Oliveras, R., et al. "The European Registry on Obstetric Antiphospholipid Syndrome (EUROAPS): A survey of 1000 consecutive cases." Autoimmunity Reviews 18.4 (2019): 406-14. D0l: 10.1016/j.autrev.2018.12.006 24. Thomopoulos, C., Salamalekis, G., Kintis, K., et al. "Risk of hypertensive disorders in pregnancy following assisted reproductive technology: overview and meta-analysis." J Clin Hypertens 19.2 (2017): 173-83. D0l: 10.1111/ich.12945 25. Jing Gui, Zhonghui Ling, Xiaojing Hou, et al. "In vitro fertilization is associated with the onset and progression of preeclampsia."Placenta 89 (2020): 50-7. D0l: 10.1016/j. placenta.2019.09.011

\section{MATERNAL FACTORS OF PRE-ECLAMPSIA DEVELOPMENT}

L.I. Berlinska, assistant, Department of Obstetrics and Gynecology, Odesa National Medical University, Odesa

V.G. Marichereda, MD, professor, Department of Obstetrics and Gynecology, Odesa National Medical University, Odesa

M.Y. Holubenko, MD, professor, Department of Obstetrics and Gynecology, Odesa National Medical University, chief physician of the Maternity Hospital No. 2, Odesa

0.M. Pavlovska, PhD, assistant, associate professor, Department of Obstetrics and Gynecology, Odesa National Medical University, Odesa

Study objective: to determine the most important maternal factors for the pre-eclampsia (PE) prediction, which are used in screening of women when registered for pregnancy.

Materials and methods. A prospective cohort study included 91 pregnant women in their first trimester; study period 2018-2020. The main group included 56 (61.54\%) women with a number of maternal factors for PE development, and 35 (38.46\%) were healthy females in the control group. Subgroups of women formed for females with and without PE - $28.57 \%$ and $71.43 \%$, respectively.

Results. Statistically significant values in the study of maternal factors were observed between subgroups of patients with and without PE for body mass index (BMI) prior to pregnancy (26.83 \pm 1.29 and $26.03 \pm 1.05$ ) and height of pregnant women $(163.35 \pm 1.26 \mathrm{~cm}$ and $167.23 \pm 1.02 \mathrm{~cm}), p<0.05$. Among the risk factors that led to PE, statistically significant results were observed when combining the first pregnancy with a history of kidney disease $(p=0.033)$. Recurrent $P E$ was observed when combined with PE history in mother $(p=0.011)$. Impact of chronic hypertension on the PE development was noted when the disease history was over 5 years. The combination of interval between pregnancies of 10 years and more and age $>35$ years was associated with $P E(p=0.008)$.

During IVF PE developed in combination with such factors as BMI $30 \mathrm{~kg} / \mathrm{m}^{2}$ and the interval between pregnancies over 10 years, $1.1 \%$ females had no other factors. History of renal disease and the age $>35$ years had an impact on the PE development in patients with anti-phospholipid syndrome. Analysis of the odds ratio of the isolated maternal factor showed the following indicators: PE during previous pregnancy - 6, multiple pregnancy - 2.56, anti-phospholipid syndrome -2.56 , first pregnancy -1.83 , in vitro fertilization -1.72 , obesity $>30 \mathrm{~kg} / \mathrm{m}^{2}-1.65$, PE in the mother -1.57 , age $>35$ years -1.08 , history of renal disease -1 , interval between pregnancies $>10$ years -0.77 and chronic hypertension -0.18 .

Conclusion. Thorough monitoring of maternal risk factors for PE should focus on PE during previous pregnancy. The second position is occupied by multiple pregnancy and anti-phospholipid syndrome. PE risk is increased for a combination of factors, especially with chronic renal disease and/or elevated BMI.

Keywords: preeclampsia, obesity, height, first pregnancy, chronic kidney disease.

\section{МАТЕРИНСЬКІ ЧИННИКИ В РОЗВИТКУПРЕЕКЛАМПСІЇ}

Л.І. Берлінська, асистент кафедри акушерства та гінекології ОНМедУ, м. Одеса

В.Г. Марічереда, д. мед. Н., професор кафедри акушерства і гінекології ОНМедУ, м. Одеса

М.Ю. Голубенко, д. мед. Н., професор кафедри акушерства та гінекології ОНМедУ, головний лікар пологового будинку №2, м. Одеса

О.М. Павловська, к. мед. Н., доцент кафедри акушерства та гінекології ОНМедУ, м. Одеса

Мета дослідження: визначити найбільш вагомі материнські фактори прогнозування прееклампсї (ПЕ), які використовуються у скринінгу жінок під час постановки на облік за вагітністю.

Матеріали та методи. У 2018 -2020 роках було проведене проспективне когортне дослідження 91 вагітної жінки у I триместрі гестації, з яких основну групу склали 56 (61,54\%) жінок, у котрих було виявлено ряд материнських факторів щодо розвитку прееклампсії, та 35 (38,46\%) здорових жінок, котрі склали контрольну групу. В подальшому сформовано підгрупи жінок з ПЕ та жінок без ПЕ - 28,57\% та 71,43\% відповідно. Результати. (татистично значимі середні показники при дослідженні материнських чинників спостерігались між підгрупами з ПЕ та без ПЕ при аналізі індексу маси тіла (ІМТ) до вагітності (26,83 $\pm 1,29$ та 26,03 $\pm 1,05)$ та

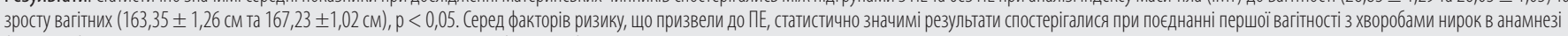

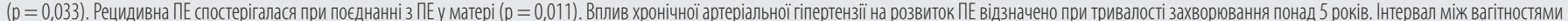
10 та більше років у розвитку ПЕ пов'язаний з віком вагітної старше 35 років ( $p=0,008)$. При екстракорпоральному заплідненні ПЕ розвинулась у поєднанні 3 такими факторами, як ІМТ > 30 кг/м² та інтервал між вагітностями більше 10 років, а 1,1\% жінок не мали інших чинників. Захворювання нирок в анамнезі та вік вагітної старше 35 років мали вплив на розвиток ПЕ при антифосфоліпідному синдромі. При аналізі відношення шансів ізольованого материнського чинника були отримані наступні показники: ПЕ під час попередньої вагітності - 6, багатоплідна вагітність - 2,56, антифосфоліпідний синдром - 2,56, перша вагітність - 1,83, екстракорпоральне запліднення - 1,72, ожиріння (IMT > 30 кг/M² ) - 1,65, ПЕу матері - 1,57, вік 35 років або старше - 1,08, захворювання нирок в анамнезі - 1, інтервал між вагітностями >10 років - 0,77 та хронічна артеріальна гіпертензія $-0,18$.

Висновок. При ретельному моніторингу материнських факторів ризику ПЕ в нашому дослідженні найвагомішим чинником є ПЕ під час попередньої вагітності. Другу позицію займає багатоплідна вагітність та антифосфоліпідний синдром. Проте при поєднанні факторів, особливо з хронічними захворюваннями нирок та/або підвищеним IMT, ризик розвитку ПЕ збільшується.

Ключові слова: прееклампсія, ожиріння, зріст, перша вагітність, хронічні захворювання нирок.

\section{МАТЕРИНСКИЕ ФАКТОРЫ В РАЗВИТИИ ПРЕЭКЛАМПСИИ}

Л.И. Берлинская, ассистент кафедры акушерства и гинекологии ОНМедУ, г. Одесса

В.Г. Маричереда, д. мед. Н., профессор кафедры акушерства и гинекологии ОНМедУ, г. Одесса

М.Ю. Голубенко, д. мед. н., профессор кафедры акушерства и гинекологии ОНМедУ, главный врач роддома №2, г. Одесса

0.Н. Павловская, к. мед. н., доцент кафедры акушерства и гинекологии ОНМедУ, г. Одесса

Цель исследования: определить наиболее значимые материнские факторы прогнозирования преэклампсии (ПЭ), которые используются в скрининге женщин при постановке на учет по беременности.

Материалы и методы. В 2018-2020 годах было проведено проспективное когортное исследование 91 беременной женщины в I триместре гестации. Основную группу составили 56 (61,54\%) женщин, у которых был выявлен ряд материнских факторов, способствующих развитию ПЭ, и 35 (38,46\%) здоровых женщин, составивших контрольную группу. В дальнейшем были сформированы две подгруппы: женщины с ПЭ и женщины без ПЭ- 28,57\% и 71,43\% соответственно.

Результаты. (татистически значимые средние показатели при исследовании материнских факторов наблюдались между подгруппами женщин с ПЭ и без ПЭ при анализе индекса массы тела (ИМТ) до беременности (26,83 $\pm 1,29$ и 26,03 $\pm 1,05)$ и роста беременных (163,35 $\pm 1,26$ см и 167,23 $\pm 1,02$ см), p < 0,05. (реди факторов риска, которые привели к ПЭ, статистически значимые результаты наблюдались при ассоциации первой беременности с болезнями почек в анамнезе ( $p=0,033)$ и рецидивной ПЭ с ПЭ у матери ( $p=0,011)$. Влияние хронической артериальной гипертензии на развитие ПЭ отмечено при длительности заболевания более 5 лет. Интервал между беременностями 10 и более лет в развитии ПЭ связан с возрастом беременной старше 35 лет ( $p=0,008)$. При экстракорпоральном оплодотворении ПЭ развилась в сочетании с такими факторами, как ИМТ < 30 кг/м² и интервал между беременностями больше 10 лет, у 1,1\% женщин не было других факторов. Антифосфолипидный синдром у женщин с ПЭ сочетался с заболеванием почек в анамнезе и с возрастом старше 35 лет. При анализе отношения шансов изолированного материнского фактора были получены следующие показатели: ПЭ во время предыдущей беременности - 6, многоплодная беременность - 2,56, антифосфолипидный синдром - 2,56, первая беременность - 1,83, экстракорпоральное оплодотворение - 1,72, ожирение (ИМт > 30 кг/м²) - 1,65, ПЭ у матери - 1,57, возраст 35 лет или старше - 1,08, заболевания почек в анамнезе - 1, интервал между беременностями > 10 лет - 0,77 и хроническая артериальная гипертензия - 0,18.

Вывод. При тщательном мониторинге материнских факторов риска ПЭ в нашем исследовании наиболее значимым является ПЭ во время предыдущей беременности. Вторую позицию занимает многоплодная беременность и антифосфолипидный синдром. Однако при сочетании факторов, особенно схроническими заболеваниями почек и/или повышенным ИМТ, риск развития ПЭ увеличивается. 